УДК 373.24

\title{
ФОРМИРОВАНИЕ ДУХОВНО-НРАВСТВЕННЫХ ЦЕННОСТЕЙ НА МУЗЫКАЛЬНЫХ ЗАНЯТИЯХ В ДОУ
}

\author{
Мерцалова Татьяна Владимировна \\ музыкальный руководитель \\ высшей квалификационной категории
}

МКДОУ «Детский сад комбинированного вида» №5, пос. Мга

\begin{abstract}
Аннотация: В условиях изменившегося духовно-нравственного состояния современного человека, роль предметов эстетического цикла как нельзя более актуальна и значима. Художественно-эстетическое воспитание является одним из важнейших компонентов формирования личности ребёнка. Именно искусство с его концентрированной эмоциональной энергией художественного образа способно не только развивать творческие способности маленького человека, совершенствовать его специфические умения и навыки, но и одновременно решать задачи развития ассоциативнообразного мышления, совершенствования эмоционального мира ребёнка, формирования его нравственно-эстетических критериев.
\end{abstract}

Ключевые слова: духовно-нравственное воспитание, дошкольное образование, воспитание ребёнка, духовные ценности, патриотизм.

\section{FORMATION OF SPIRITUAL AND MORAL VALUES IN MUSIC CLASSES IN PRESCHOOL EDUCATIONAL ORGANISATION}

\section{Mertsalova Tatiana Vladimirovna}

\begin{abstract}
In the context of the changed spiritual and moral state of modern person, the role of the aesthetic cycle subjects is as relevant and significant as possible. Artistic and aesthetic education is one of the most important components of the formation of a child's personality. It is art with its concentrated emotional energy of the artistic image can not only develop the creative abilities of a little person, but also improve his specific skills and abilities. Art lessons can solve the problems of developing associative and imaginative thinking, problems with improving the emotional world of a child, forming his moral and aesthetic criteria.
\end{abstract}


Key words: spiritual and moral education, preschool education, child education, spiritual values, patriotism.

Разностороннее воспитание и образование ребёнка - насущная задача современности. Это задача и родителей, и образовательных институтов. Разностороннее воспитание предполагает, что личность развивается гармонично - на уровнях рациональном, волевом, эмоциональном. Каждая из этих личностных направленностей связана с духовным миром человека. Поэтому, если не уделять достаточно внимания эстетическому воспитанию дошкольника, его внутренний, духовный мир будет «обеднён». Эстетическое воспитание может и должно быть дополнено воспитанием нравственности. Речь о ценностях: лучшая «прививка» против принятия подростками ложных и иллюзорных ценностей (в будущем) - это закладывание в культурный код ребёнка (уже в дошкольном образовательном учреждении) ценностей подлинных, основанных на богатстве русской культуры. Формирование духовно-нравственных ценностей личности требует моделирования определенных педагогических условий.

Цель данной работы - раскрыть возможности формирования духовноценностных ценностей детей-дошкольников посредством интеграции усилий музыкального руководителя, воспитателя, местных мастеров народного творчества, родителей на музыкальных занятиях в ДОУ.

Справедливым будет отметить, что «обеспечение духовнонравственного развития и воспитания личности гражданина России является ключевой задачей современной государственной политики Российской Федерации» [1, с. 453]. О приоритете духовно-нравственного воспитания подрастающего поколения в современной России говорит и православная Церковь: «Если в XX веке процветала наивная вера во всемогущество материального прогресса, то в XXI веке будущее принадлежит тем народам, которые смогут обеспечить мощное духовно-нравственное осмысление материального развития и адаптировать свою образовательную систему к этим реалиям жизни» [2, с. 147].

Вступивший в силу в 2014 г. ФГОС ДО одной из приоритетных педагогических задач называет духовно-нравственное воспитание дошкольников. «Концепция духовно-нравственного воспитания и развития личности», которая является одним из источников нового ФГОС ДО, предполагает построение воспитания и образования на принципах следования 
семейным, социальным и государственным отечественным традициям. Воспитание невозможно без приобщения детей к общепринятым социокультурным нормам российского общества.

Федеральный Стандарт направлен на решение важной задачи, а именно - объединение обучения и воспитания в единый образовательный процесс, основанный на духовно-нравственных и социокультурных ценностях. В раздел «Целевые ориентиры на этапе завершения дошкольного образования» Стандарта включены такие показатели:

«ребёнок способен к волевым усилиям, может следовать социальным нормам поведения и правилам в разных видах деятельности, во взаимоотношениях со взрослыми и сверстниками; обладает начальными знаниями о себе, о природном и социальном мире, в котором он живёт; знаком с произведениями детской литературы, обладает элементарными представлениями из области живой природы, естествознания, математики, истории и т.п.; ребёнок способен к принятию собственных решений, опираясь на свои знания и умения в различных видах деятельности» [3].

В МКДОУ «Детский сад комбинированного вида» №5 пос. Мга Ленинградской области на музыкальных занятиях мы стараемся, чтобы дети имели возможность познакомиться с азами православной культуры. Для этого необходимо, безусловно, учитывать духовно-нравственный потенциал и соответствующие педагогические компетенции педагогов, a также заинтересованность родителей. Включение элементов православного воспитания в дошкольное образовательное учреждение «не противоречит задачам светского воспитания, установленным федеральным государственным образовательным стандартом дошкольного образования, а обогащает и дополняет педагогический процесс» [4, с. 55].

Модуль «Основы православной культуры» (ОПК, часть курса ОРКСЭ основ религиозных культур и светской этики), который сегодня уверенно вошёл в образовательный процесс в школах, вовсе не является вероучительной дисциплиной в смысле дореволюционного «Закона Божия», который изучали в школах. Новая дисциплина ОПК - культурологический и религиоведческий предмет, «навязывание» религиозного мировоззрения просто не стоит на повестке дня. Согласно ст. 64.1 Федерального Закона «Об образовании в Российской Федерации» № 273-Ф3, - «Дошкольное образование направлено на формирование общей культуры, развитие физических, интеллектуальных, нравственных, эстетических и личностных 
качеств (...)» [5]. В дошкольном образовательном учреждении выбор направленности или содержательного наполнения образовательного и воспитательного процесса определяется исходя из запросов воспитанников (их родителей или законных представителей). Вариативность дошкольного образования, т.е. возможность варьировать образовательные программы в соответствии с законом и запросами законных представителей ребёнка, даёт возможность включения элементов ОПК, не предусмотренных федеральным компонентом государственного стандарта [6].

Воспитание в широком контексте рассматривается как цุелостный социально-педагогический феномен, сущность которого - создание педагогических условий для развития гармоничной личности. Воспитание способствует социализации человека, восприятия им определенных ценностей, мировоззрения, убеждений. Как отмечают некоторые современные исследователи в дошкольном возрасте восприятие ценностей и убеждений происходит не напрямую, а через эмоции, т.е. иррационально (подробнее см.: [7]).

Формирование духовно-нравственных ценностей напрямую связано с одним из основных принципов христианской веры - «возлюби ближнего своего, как самого себя» (Мф 22:39). Этот принцип входит в общечеловеческую мораль, выраженную в «золотом правиле нравственности» - «как хотите, чтобы с вами поступали люди, так и вы поступайте с ними» (Лк 6:31). Другой вариант этого принципа - «не делай другому того, чего не желаешь себе». Следуя этим понятным принципам, мы должны воспитать у детей такие чувства как любовь, доброта, честность, взаимопомощь, самопожертвование. Поэтому с младших групп акцентируется внимание на таких ценностях как любовь. Особенное внимание мы уделяем теме материнской любви.

Прослушивание музыкальных песен, чтение сказок, в которых наиболее выразительно показана сила материнской любви, помогают привить детям важность помощи своей маме, внимательное отношение к ней. Праздники «День Матери» и «Международный женский день 8 марта» активизируют и творчески оформляют работу по духовно-нравственному воспитанию. $\mathrm{He}$ могут не оставить свой след в маленькой детской душе такие образовательновоспитательные элементы как: заучивание стихов о матери, изготовление hand-made подарков (творческие работы: «портрет мамы» или картина «Семья»), совместные творческие задания для детей и их родителей. 
Полноценное восприятие ребёнком духовно-нравственных ценностей на эмоциональном уровне невозможно без родительского внимания. Слыша ещё в колыбели песни матери, позднее - то, как она читает сказки, стихи, или загадки, - ребёнок естественным образом (иррационально) усваивает не только богатство народной культуры своего народа, но и основы традиционной духовно-нравственной культуры. В наше время высоких технологий и тотального проникновения этих технологий в повседневную жизнь такие простые и понятные социальные связи (даже между родителями и их детьми) утрачиваются. Возрастает разобщённость между детьми и родителями, в том числе потому, что большую часть своего времени дети проводят в созерцании бездушных экранов различных гаджетов. В то время как «живой», традиционный фольклор (колыбельные песни, «сказки на ночь», детские игры) - необходимый компонент разностороннего, гармоничного развития творческой личности ребёнка.

Воспитание детей на традициях народной культуры является одним из важных средств патриотического, нравственного и эстетического воспитания. Поэтому не стоит обходить вниманием и церковные праздники, учитывая то, что период клеймления их как явлений религиозного обскурантизма (в советское время) уже давно прошёл.

Многие русские народные праздники сопровождались напоминающими театральное представление действиями, которые сегодня могут казаться необычными и даже непонятными. Как возникли традиции на Рождество ходить от дома к дому и петь колядки? Почему на Масленицу люди пекут блины, делают соломенное чучело и бросают его в костёр? Почему на Пасху пекут куличи и красят яйца? Такова традиция, корни которой уходят во времена седой старины [8]. Почему бы не познакомить детей с этими замечательными традициями, рассказать об их истории, обогатив тем самым их восприятие народной культуры и истории.

Музыкальный фольклор здесь выступает в роли универсального средства эстетического и нравственного воспитания. Занятия фольклором способствуют общему творческому развитию личности, что, в свою очередь, «воспитывает отзывчивость, художественное воображение, образноассоциативное мышление, активизирует память, наблюдательность, интуицию, формирует внутренний мир ребёнка» [9, с. 192-193].

Духовно-ценностное отношение к жизни неразрывно связано с Верой и Отечеством. Основой русского слова «Отечество» является слово «Отец». Всё 
в мире берёт начало от отца, как единого начала, и это Небесный Отец, о котором говорит нам христианская вера. Понятие «Отечество» появилось в русских летописях во второй половине XIV века. Сегодня того, кто любит Отечество, называют патриотом. Патриоту свойственны преданность Отечеству, служение интересам Отечества, привязанность к родной земле, языку, вере, культуре, традициям своего народа, которые сформировались в течение столетий. Патриотизм также является духовно-нравственной ценностью, формирующей гражданскую идентичность личности.

Из истории нашего Отечества можно привести множество примеров проявления патриотизма. Это святые: равноапостольный князь Владимир, князь Ярослав Мудрый, Владимир Мономах, Андрей Боголюбский, Александр Невский, Димитрий Донской... И этот список можно продолжать долго. Не стоит забывать и героев наших дней: Евгения Родионова, не снявшего с себя православный крест и не предавшего веру и Отечество, с его друзьями-пограничниками: Игорем Яковлевым, Андреем Трусовым, Александром Железновым, Псковскими десантниками, погибшими в Чеченской войне. Это наши современные герои, и дети должны о них знать. Для этого в свою работу с детьми музыкальный руководитель включает «уроки мужества»- 23 февраля, 9 мая.

Приобщение детей к истокам, к основам духовности происходит на праздниках православного календарного цикла; такие праздники как Рождество, Масленица, Пасха раскрывают и русский народный фольклор, и богатство духовной культуры. Проведение экскурсий в православный храм, знакомство с азами христианства способствует установлению духовной, творческой атмосферы в группах.

Однако важно, чтобы материал был подобран в соответствии с возрастными особенностями детей. Музыкальное занятие, объединяющее искусство, фольклор и религию, выступает как интегративная система, показывающая традиционный уклад и комплекс взглядов и убеждений русского народа, выработанных на протяжении многих сотен лет.

Для обеспечения успешной работы следует позаботиться о создании материально-технической базы музыкальных занятий (использование ИКТ, TCO, музыкальных инструментов: фортепиано, баян, ложки, бубны, свистульки, бубенцы, колокольчики, дудочки, и т.д.). Так же в обучении большую роль играет наглядность. Она должна выражаться как в слуховых, так и в зрительных впечатлениях. Поэтому следует разрабатывать 
разнообразные тематические презентации: игры, театрализованные действия, показ предметов народных промыслов, домашней утвари. В музыкальном зале может быть оборудован уголок православной культуры, где собран теоретический и практический материал.

Опыт проведения музыкальных занятий данной направленности показывает, что эти занятия способствуют

$\checkmark$ установлению творческой атмосферы;

$\checkmark$ собственному духовному совершенствованию педагога;

$\checkmark$ духовному совершенствованию детей и их родителей;

$\checkmark$ развитию высоконравственной гражданской позиции и совести;

$\checkmark$ воспитанию у детей представлений о добродетели и милосердии;

Духовно-нравственное воспитание решает ряд педагогических задач, таких как:

$\checkmark$ обогащение духовного мира ребёнка;

$\checkmark$ развитие творческих способностей дошкольников;

$\checkmark$ знакомство детей с разнообразными формами детского музыкального фольклора;

$\checkmark$ знакомство детей с традициями, обрядами и образами русского народа;

$\checkmark$ знакомство с народными инструментами;

$\checkmark$ знакомство с основами православной культуры;

$\checkmark$ развитие устной речи;

$\checkmark$ развитие эмоционального восприятия в различных видах музыкальной деятельности;

$\checkmark$ расширение представлений детей о народных праздниках, обычаях и традициях русского народа;

$\checkmark$ воспитание эстетических чувств;

$\checkmark$ воспитание устойчивого интереса и любви к своей вере, своему народу, народному искусству.

Использование различных видов и форм творческих занятий в контексте музыкальных занятий в ДОУ позволит достичь ожидаемых результатов.

\section{Список литературы}

1. Бикетова Н. В. Духовно-нравственное развитие и воспитание дошкольников в условиях введения новых стандартов // Наука и образование: новое время. - 2016. - № 6 (17). - С. 453-456. 
2. Кирилл (Гундяев), патр. Вера и образование. Выступление на XVI Международных Рождественских образовательных чтениях «Православные ценности и современное образование» (Москва, 27 января - 2 февраля 2008 г.) // Церковь и время. - 2008. - № 2 (43). - С. 5-20.

3. Приказ Министерства образования и науки Российской федерации от 17 октября 2013 г. № 1155 «Об утверждении федерального государственного образовательного стандарта дошкольного образования» // СПС КонсультантПлюс.

4. Демченко Э. Н. Православные ценности как один из важных компонентов духовно-нравственного воспитания дошкольников // Сборник: Наука в современном мире. Материалы XXIX Международной научнопрактической конференции. Центр научной мысли. - 2017. - С. 54-58.

5. Федеральный закон «Об образовании в Российской Федерации» от 29.12.2012 № 273-Ф3 // СПС КонсультантПлюс.

6. Смольникова Е. И. Я иду на урок в начальную школу: Основы православной культуры: Книга для учителя. - М.: Издательство «Первое сентября», $-2001 .-256$ с.

7. Ежкова Н. С. Теория и практика эмоционально развивающего воспитания и образования детей дошкольного возраста. Дисс. кан. пед. наук. M. $-2009 .-366$ c.

8. Бударина Т. А., Куприна Л. С., и др. Знакомство детей с русским народным творчеством. - СПб: «Детство - Пресс», - 1999. - 384 с.

9. Харлашко М. А. О важности формирования артистических навыков у учащихся младшего школьного возраста на уроках академического вокала // Вестник МГУКИ. - 2008. - №1. - С. 192-193.

(C) Т.В. Мерцалова, 2021 